\title{
Characterization and Pyrometallurgical Removal of Arsenic from Copper Concentrate Roasting Dust
}

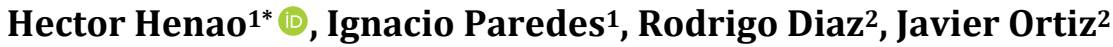 \\ ${ }^{1}$ Metallurgy Engineering Department, Technical University Federico Santa María, Valparaíso, Chile \\ ${ }^{2}$ CODELCO, Ministro Hales Division, Antofagasta, Chile \\ Email: ^hector.henao@usm.cl, ignacio.paredes@alumnos.usm.cl, RDiaz015@codelco.cl, JOrti027@codelco.cl
}

How to cite this paper: Henao, H., Paredes, I., Diaz, R. and Ortiz, J. (2021) Characterization and Pyrometallurgical Removal of Arsenic from Copper Concentrate Roasting Dust. Journal of Minerals and Materials Characterization and Engineering, 9, 609620.

https://doi.org/10.4236/jmmce.2021.96039

Received: October 20, 2021

Accepted: November 15, 2021

Published: November 18, 2021

Copyright $\odot 2021$ by author(s) and Scientific Research Publishing Inc. This work is licensed under the Creative Commons Attribution International License (CC BY 4.0).

http://creativecommons.org/licenses/by/4.0/

\begin{abstract}
This paper describes the experimental results of removing arsenic from the dust collected in electrostatic precipitators of a fluidized bed roasting furnace (RP dust). The fluidized bed roasting process generates 600 kilotons of copper concentrate per year with $3-6 \mathrm{wt} \%$ of concentration of arsenic, producing a roasted product with a low content of arsenic below $0.3 \mathrm{wt} \%$. The process generates 27 kilotons of RP dust per year with a concentration of arsenic of the order of $5 \mathrm{wt} \%$ and copper concentration of around $20 \mathrm{wt} \%$. Subsequently, the dust collected in the electrostatic precipitators is treated by hydrometallurgical methods allowing the recovery of copper, and the disposition of arsenic as scorodite. This work proposes to use a pyrometallurgy process to the volatilization of arsenic from RP dust. The obtained material can be recirculated in copper smelting furnaces allowing the recovery of valuable metals. The set of experiments carried out in the roasting of the mixture of copper concentrate/RP dust and sulfur/RP dust used different ratios of mixtures, temperatures and roasting times. By different techniques, the characterization of the RP dust determined its size distribution, morphology, and chemical and mineralogical composition. RP dust is a composite material of small particles $(<5 \mu \mathrm{m})$ in $50 \mu \mathrm{m}$ agglomerates, mostly amorphous, with a complex chemical composition of sulfoxides. The results of the roasting experiments indicated that for a 75/25 weight ratio of the mixture of the copper concentrate/PR dust under $700^{\circ} \mathrm{C}, 15$ minutes of roasting time with injection of air, the volatilization of arsenic reached $96 \%$ by weight. The arsenic concentration after the roasting process is less than $0.3 \%$ by weight. For a $5 / 95$ mixture of sulfur/RP dust, at $650^{\circ} \mathrm{C}$, the volatilization of arsenic reached a promissory result of $67 \%$. Even that this study was carried out for a particular operation,
\end{abstract}


the results have the potential to be extended to dust produced in the roasting of concentrates of nickel, lead-zinc, and gold.

\section{Keywords}

Copper Smelter Dust, Electrostatic Precipitators of Copper, Removal of Arsenic, Sulfidation, Roasting Process, Fluidized Bed Roasting

\section{Introduction}

Worldwide, sulfide concentrates of copper, gold, and nickel with high arsenic content are treated in roasting furnaces, obtaining calcines with low concentrations of arsenic. The obtained calcine is appropriate for further metallurgical operations for the recovery of valuable metals [1] [2] [3] [4] [5]. In Chile, a copper concentrate with a high content of arsenic is roasted in a fluidized bed furnace, which processes 600 kilotons of copper concentrate per year, generating an off-gas rich in arsenic that during the process of gas cooling produce 26 kilotons of fine particles of dust (RP dust) [6] [7]. This dust is collected in electrostatic precipitators [6] [7] [8] and further processed by hydrometallurgical techniques allowing to recover copper and other valuable metals [6] [7]. The arsenic dissolved when the leaching process is disposed of as a precipitate of scorodite [6] [7].

The literature described the treatment of dust by the hydrometallurgy process. It is reported a low recovery of copper (60 - $70 \mathrm{wt} \%)$, a considerable generation of solid residues (around $40 \mathrm{wt} \%$ of the original material) [9] [10], and requirement of high consumption of chemicals materials. In addition, there is uncertainty regarding the long-term stability of the scorodite or other solid heavy metal residues generated [1] [11] [12]. In terms of stability, it reports that the fixation of arsenic as a glassy material is the best option just as it keeps the arsenic stable for geological periods.

To produce a glassy residue, it is desirable a waste material with a high concentration of arsenic oxides [1] [11]. Pyrometallurgical treatment of RP dust has the potential to increase the recovery of copper (and other valuable metals), reduce solid residues, and generate condensed gases with a high concentration of arsenic oxides [13] [14] [15] [16] [17].

In a recent publication, it was demonstrated the technical possibility of pyro-metallurgical volatilizing arsenic from a Flash Smelting Furnace dust [13]. However, there are no reported studies related to the characterization of dust from the roasting of sulfur concentrates with high arsenic content or works related to the volatilization of arsenic from roasting metallurgical dust. Thus, the main aim of this work is to characterize the RP dust. Additionally, the work evaluated, at a laboratory scale operation, parameters such as temperature, roasting time, and gas atmospheres necessary for arsenic volatilization in mixtures of copper concentrate/RP dust, sulfur/RP dust, or pyrrhotite/RP dust. 


\section{Materials and Methods}

\subsection{Copper Concentrate with a High Concentration of Arsenic}

An essential section of this work comprises roasting experiments of copper concentrate mixtures with a high concentration of arsenic and RP dust. The characterization and roasting behavior of this concentrate was reported in a previous paper [13]. The concentrate sample indicated arsenic contained in minerals of enargite/tennantite $\left(\mathrm{Cu}_{3} \mathrm{AsS}_{4} / \mathrm{Cu}_{12} \mathrm{As}_{4} \mathrm{~S}_{13}\right)$. The main observed minerals were Chalcocite/Digenite, Enargite/Tennantite, and Pyrite, in minor proportion are present Chalcopyrite and Bornite. The elemental chemical composition is included in Table 1.

\subsection{Characterization of the RP Dust}

The experimental set worked on the dust collected from the electrostatic precipitators of a Bed Roasting Furnace (RP dust). Thus, a number of analysis were carried out to determine in the sample the size distribution, mineralogical composition, distribution of arsenic in each of the phases and elemental composition.

Table 1 displays the elemental composition by Atomic Adsorption Spectroscopy (AAS) (AAS Perkin Elmer, Model: PinAAcle 900F Flame) analysis, reporting a concentration of copper of 17.2 (wt\%) and a concentration of arsenic of 4.4 wt\%. Quantitative data collected for the arsenic concentration by AAS analysis will be used in future calculations. This table also includes the concentration of copper with a high concentration of arsenic used in the experiments.

Table 2 shows the results obtained using a Quantitative Evaluation of Minerals by Scanning Electron Microscopy QEMSCAN (TSCAN, Model: VEGA3 LM). Arsenic is present as a multi-component material of $\mathrm{Cu}-\mathrm{Fe}-\mathrm{As}-\mathrm{S}-\mathrm{O}$ and chenevixite, copper as bornite and Chalcocite/Digenite. The sample also contains micas, quartz among other minor components.

Figure 1 exhibits the size distribution of an RP dust obtained by using hydro cyclone sizers, indicating that $99.4 \mathrm{wt} \%$ of the sample corresponds to size under $53 \mu \mathrm{m}$ and $88 \mathrm{wt} \%$ to size under $10 \mu \mathrm{m}$.

Scanning Electron Microscope-Energy Dispersive X-ray Analysis SEM/EDS (SEM: Zeiss Evo Model: MA10, EDS: Oxford X-Act, Detector BS, Software INCA) were used to determine the phases present in the RP dust. Figure 2 includes SEM micrographs, and Table 3 summarizes the elemental chemical composition of

Table 1. Atomic Absorption (AAS) elemental chemical analysis of RP dust (wt\%) or (ppm).

\begin{tabular}{cccccccccc}
\hline Material & $\mathrm{Cu}$ & $\mathrm{Fe}$ & $\mathrm{SiO}_{2}$ & $\mathrm{~S}$ & $\mathrm{As}$ & $\mathrm{Sb}$ & $\begin{array}{c}\mathrm{Bi} \\
(\mathrm{ppm})\end{array}$ & $\begin{array}{c}\mathrm{Ag} \\
(\mathrm{ppm})\end{array}$ & insoluble \\
\hline RP dust & 17.2 & 13.6 & 20.1 & 7.7 & 4.4 & 1.0 & 100 & 460 & 11.4 \\
Concentrate & 42.1 & 11.1 & 5.0 & 30 & 5.2 & 0.3 & 68 & 486 & 6.5 \\
\hline
\end{tabular}




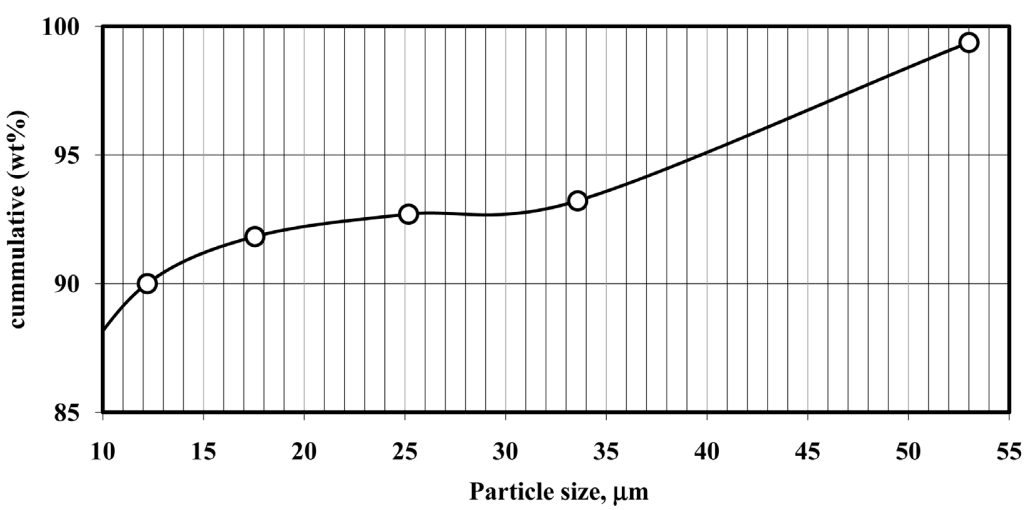

Figure 1. RP dust sample particles size distribution.
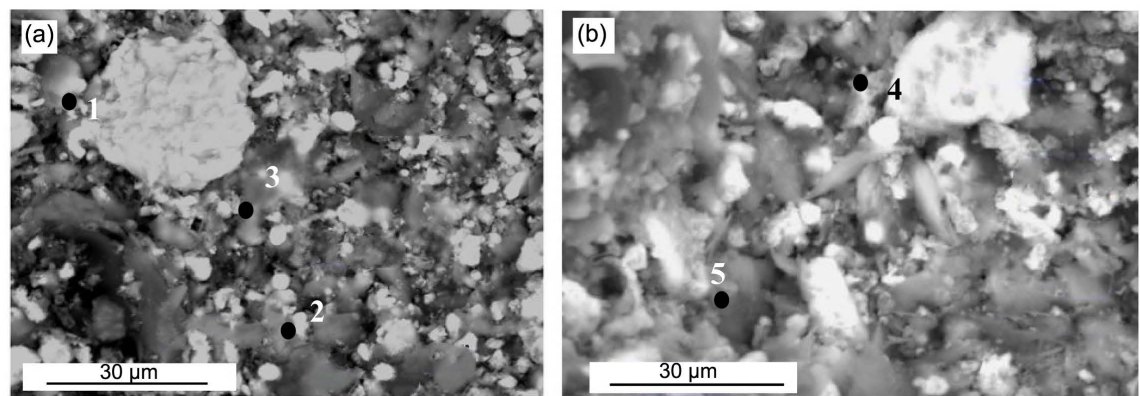

Figure 2. Scanning electron micrograph of RP dust (A) EDS analyzed points 1, 2 and 3 reported in Table 3, (B) EDS analyzed points 4 and 5 reported in Table 3.

Table 2. QEMSCAN analysis of RP dust (analysis conditions: Probe current $=4.55 \mathrm{nA}$, beam intensity: $25 \mathrm{kV}$ ).

\begin{tabular}{|c|c|c|}
\hline Phase & $\begin{array}{c}\text { Normalized } \\
\text { Mineralogical } \\
\text { Composition (wt } \% \text { ) }\end{array}$ & $\begin{array}{l}\text { As distribution } \\
\text { per phase } \\
\text { (wt } \%)\end{array}$ \\
\hline $\begin{array}{l}\mathrm{Si}-\mathrm{Fe}-\mathrm{Cu}-\mathrm{S}-\mathrm{As}-\mathrm{Al}-\mathrm{O}-\mathrm{K}-\mathrm{Cl}-\mathrm{Sb} \\
\text { Amorphous complex oxides }\end{array}$ & 58.2 & 88.1 \\
\hline Bornite: $\mathrm{Cu}_{2} \mathrm{FesS}_{4}$ & 17.1 & 0 \\
\hline $\begin{array}{c}\text { Micas (Muscovite/illita) } \\
\mathrm{KAl}_{2}\left(\mathrm{AlSi}_{3} \mathrm{O}_{10}\right)(\mathrm{F}, \mathrm{OH})_{2} /\left(\mathrm{K}, \mathrm{H}_{3} \mathrm{O}\right) \\
(\mathrm{Al}, \mathrm{Mg}, \mathrm{Fe})_{2}(\mathrm{Si}, \mathrm{Al})_{4} \mathrm{O}_{10}\left[(\mathrm{OH})_{2},\left(\mathrm{H}_{2} \mathrm{O}\right)\right]\end{array}$ & 10.5 & 0 \\
\hline Chalcocite/Digenite: $\mathrm{Cu}_{2} \mathrm{~S} / \mathrm{Cu}_{9} \mathrm{~S}_{5}$ & 3.7 & 0 \\
\hline Quartz: $\mathrm{SiO}_{2}$ & 2.3 & 0 \\
\hline Chenevixite $\mathrm{Cu}_{2} \mathrm{Fe}_{2}\left(\mathrm{AsO}_{4}\right)_{2}(\mathrm{OH})_{3}$ & 1.9 & 11.0 \\
\hline Tenorite $\mathrm{CuO}$ & 1.7 & 0 \\
\hline Hematite/magnetite: $\mathrm{Fe}_{2} \mathrm{O}_{3} / \mathrm{Fe}_{3} \mathrm{O}_{4}$ & 1.1 & 0 \\
\hline Aluminium Clays & 0.5 & 0 \\
\hline Wurtzite: ZnS & 0.4 & 0 \\
\hline Sphalerite: $(Z n, F e) S$ & 0.4 & 0 \\
\hline Others & 1.8 & 0.9 \\
\hline
\end{tabular}


Table 3. SEM/EDS analysis of RP dust (analysis condition: Acceleration voltage $=15 \mathrm{kV}$, beam current $=11 \mathrm{nA}$ ).

\begin{tabular}{|c|c|c|c|c|c|c|c|c|c|}
\hline \multirow{2}{*}{$\begin{array}{l}\text { Exp. } \\
\mathrm{N}^{\circ}\end{array}$} & \multicolumn{9}{|c|}{ Normalized elemental composition (wt \%) } \\
\hline & $\mathrm{Al}$ & $\mathrm{Si}$ & S & $\mathbf{K}$ & $\mathrm{Fe}$ & $\mathrm{Cu}$ & $\mathrm{Zn}$ & As & $\mathrm{Sb}$ \\
\hline 1 & 1.4 & 2.0 & 10.5 & 0.4 & 19.1 & 60.6 & - & 1.1 & - \\
\hline 2 & 1.5 & 2.6 & 6.2 & 0.3 & 28.4 & 23.6 & 0.4 & 7.6 & 1.6 \\
\hline 3 & 1.9 & 2.5 & 10.2 & 0.4 & 21.2 & 41.1 & 0.9 & 3.3 & 0.8 \\
\hline 4 & 2.3 & 2.4 & 8.8 & 0.3 & 24.3 & 29.1 & - & 5.2 & 1.1 \\
\hline 5 & 1.5 & 2.3 & 15.4 & 0.5 & 23.9 & 47.1 & - & 4.1 & 1.0 \\
\hline
\end{tabular}

the selected points analyzed by EDS (note: the balance to $100 \mathrm{wt} \%$ correspond to oxygen). The analyses indicated that the particles have a few microns in size, and some of them appear as agglomerates, there are no appreciable visual differences between the particles or indication of any crystal formation. In addition, as indicated in the results of Table 3, it is difficult to assign crystals compositions to the analyzed points by EDS, which is an indication that the RP dust corresponds mostly to amorphous polymetallic sulfoxide.

The result of the X-ray diffraction (XRD) (XRD STOE, Model: STADI_MP, Detector DECTRIS MYThem $1 \mathrm{~K}$, Database Match) analysis is presented in Figure 3, which shows an amorphous material with the presence of a few peaks corresponding to complex phases of $\mathrm{Cu}-\mathrm{Fe}-\mathrm{S}-\mathrm{As}$ - $\mathrm{Al}$ as gartrellite, johillerite, and kidwellite. A qualitative agreement exists between the results of QEMSCAN, SEM/ EDS, XRD regarding the presence in the sample of Si-Fe-Cu-S-As-Al-O-K-Cl-Sb complex oxides described as Chenevixite, bornite, gartrellite, johillerite, and kidwellite.

\subsection{Experimental Equipment and Method for Arsenic Volatilization}

The experiments carried out used the same copper concentrate, equipment, and procedure previously described [13] with a reactor built from boron silicate glass to resist temperatures of $750^{\circ} \mathrm{C}$, with a sintered glass disk (fritted) forming the base of the reactor bed. All experiments realized achieved a homogeneous mixture between the gases and the sample, maintained a stable temperature and allowed similar operating conditions of an industrial fluidized bed roaster. $5 \mathrm{~g}$ of silica was as used as a bed on the fritted, and the total weight of the sample was 5 grams of copper concentrate or elemental sulfur mixed with RP dust. The sample was placed on top of the silica bed. The reactor was held inside a muffle preheated to $200^{\circ} \mathrm{C}$. During the tests, the temperature of the reactor kept a range between $600^{\circ} \mathrm{C}$ and $700^{\circ} \mathrm{C}$, with a gas (air, nitrogen, or $\mathrm{SO}_{2}$ ) flow of $10 \mathrm{ml} / \mathrm{min}$. The select flow of gases created the conditions of a fluidized bed in the reactor. Once the roasting time finished, the sample was extracted from the reactor and separated in a screen of $100 \mu \mathrm{m}$. The oversized material contained the silica, and the undersize consisted of the calcined sample. 


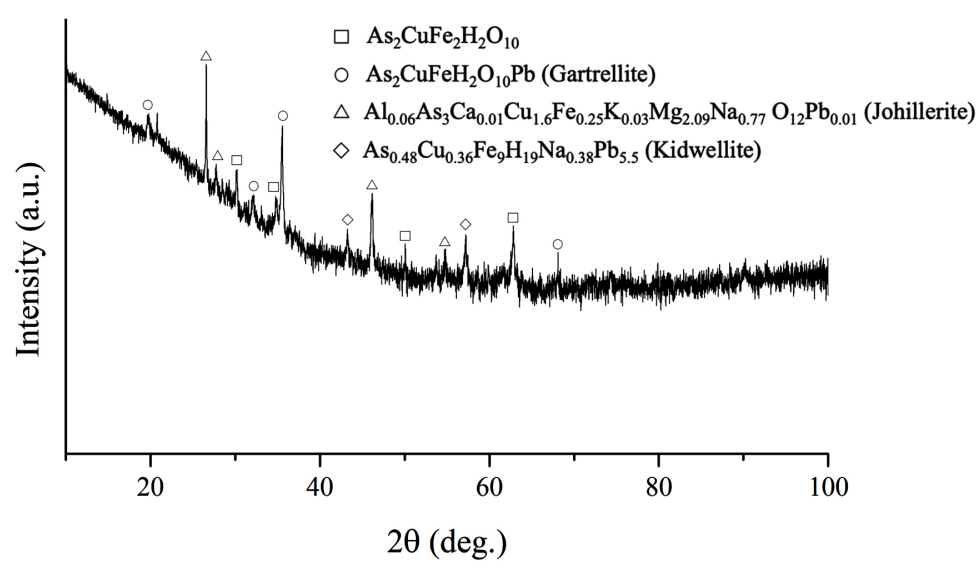

Figure 3. XRD analysis of RP dust (analysis conditions: $\mathrm{t} / \mathrm{step}=17 \mathrm{~s}$, step $=2.1,2 \theta=10$ 100 , time $=15 \mathrm{~min}$ ).

The percentage of volatilization of species $(\mathrm{X})$ was defined as:

$\%$ Volatilization $\mathrm{X}=100 \mathrm{x}\left([\mathrm{wt} \% \mathrm{X}] \mathrm{I}_{\text {nitial }}-[\mathrm{wt} \% \mathrm{X}]_{\text {final }}\right) /[\mathrm{wt} \% \mathrm{X}]_{\text {initial }}$

where $[\mathrm{wt} \% \mathrm{X}]_{\text {initial }}$ is the measured concentration of arsenic (or antimony) in the charged sample and $[\mathrm{wt} \% \mathrm{X}]_{\text {final }}$ is the measured concentration of arsenic (or antimony) after the roasting process.

\section{Results}

\section{Results of a Roasted Mixture of Copper Concentrate/RP Dust}

Preliminary roasting experiments were performed at different conditions of mixtures of copper concentrate/RP dust at $700^{\circ} \mathrm{C}$. The temperature was selected according to the results obtained in the previous paper [13], where at $700^{\circ} \mathrm{C}$ was observed the highest arsenic volatilization for the copper concentrate. The results indicated in Figure 4 includes a mass balance for the calculation considering volatilization of arsenic of zero from the RP dust in a mixture of concentrate/RP dust, the results are indicated in this figure as squares while the experimental results of the mixture concentrate/RP dust as circles. By comparing the lines of trends, it is possible to state that only for mixtures with ratios of copper concentrate/FS dust above 50/50 a significant volatilization of arsenic was obtained. It is interesting to observe that FS dust [13] and RP dust mixed with copper concentrate show similar behavior, for mixtures with ratios lower than $30 / 70$, the volatilization of arsenic is negligible. Thus, from an operational point of view, a large proportion of copper concentrate would be required to volatilize the arsenic contained in the RP dust.

Based on the results of Figure 4, a set of experiments were carried out for the mixture of copper concentrate/RP dust in a ratio of $75 / 25$, under a roasting time of 15 minutes, varying the temperature in the range of 600 to 700 degrees. The experimental conditions, results of AAS chemical analysis of arsenic and volatilization of arsenic are included in Table 4 . The table also comprises experiments for a mixture of sulfur/RP dust in a weight ratio of 5/95. 


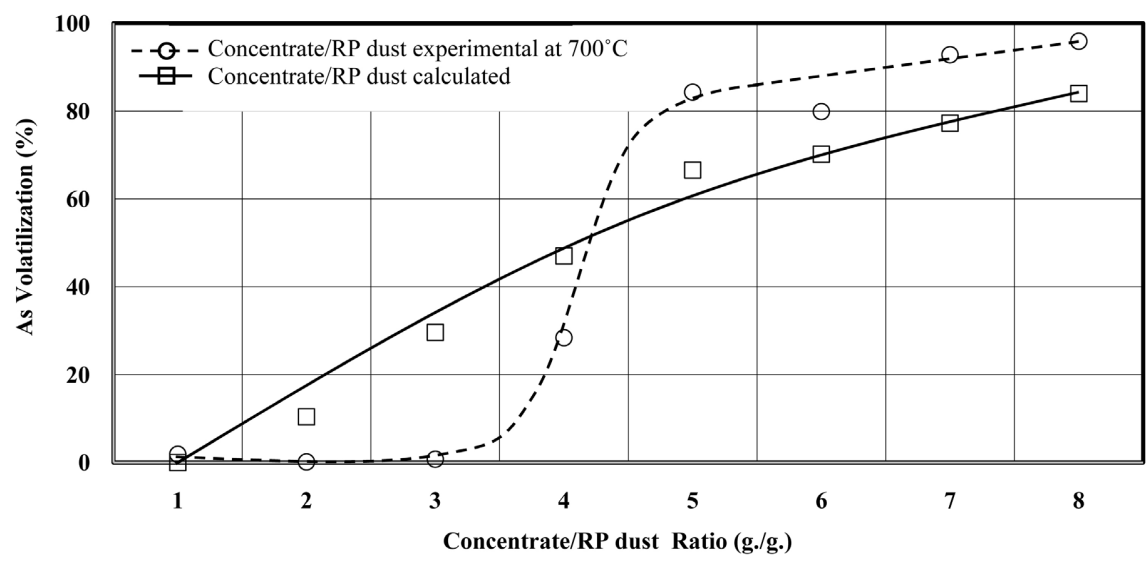

Figure 4. Volatilization of arsenic for different ratios of copper concentrate/RP dust mixture at $700^{\circ} \mathrm{C}$ and 15 minutes of volatilization.

Table 4. Volatilization of arsenic for a mixture of copper concentrate/RP dust of 75/25 and Sulfur/RP dust of 5/95, under different temperatures and roasting times.

\begin{tabular}{|c|c|c|c|c|c|}
\hline \multirow[b]{3}{*}{ Mixture } & \multirow[b]{3}{*}{ Experiment } & \multicolumn{2}{|c|}{ Experimental conditions } & \multicolumn{2}{|c|}{ Chemical Analysis (wt\%) } \\
\hline & & Time & Temperature & \multirow{2}{*}{ As } & \multirow{2}{*}{$\begin{array}{c}\text { As } \\
\text { Volatilization }\end{array}$} \\
\hline & & minutes & $\left({ }^{\circ} \mathrm{C}\right)$ & & \\
\hline \multirow{12}{*}{$\begin{array}{c}\text { Copper } \\
\text { concentrate/ } \\
\text { RP dust } \\
75 / 25 \\
\text { (wt\%/wt\%) }\end{array}$} & 1 & 2 & 600 & 2.9 & 34.8 \\
\hline & 2 & 5 & 600 & 2.9 & 33.6 \\
\hline & 3 & 10 & 600 & 3.0 & 33.0 \\
\hline & 4 & 15 & 600 & 2.9 & 34.5 \\
\hline & 5 & 2 & 650 & 2.9 & 34.3 \\
\hline & 6 & 5 & 650 & 2.7 & 40.2 \\
\hline & 7 & 10 & 650 & 2.3 & 47.9 \\
\hline & 8 & 15 & 650 & 1.8 & 59.4 \\
\hline & 9 & 2 & 700 & 2.2 & 49.9 \\
\hline & 10 & 5 & 700 & 1.3 & 69.8 \\
\hline & 12 & 10 & 700 & 0.5 & 88.0 \\
\hline & 13 & 15 & 700 & 0.2 & 96.4 \\
\hline Sulfur/RP & 14 & 15 & 600 & 3.0 & 24.0 \\
\hline dust & 15 & 15 & 620 & 1.7 & 57.3 \\
\hline \multirow{2}{*}{$\begin{array}{c}5 / 95 \\
(w t \% / w t \%)\end{array}$} & 16 & 15 & 650 & 1.3 & 67.5 \\
\hline & 17 & 15 & 700 & 1.4 & 65.8 \\
\hline
\end{tabular}

Table 5 summarizes the experimental results obtained at the conditions of $700^{\circ} \mathrm{C}$ and 15 minutes. Additional experiments of mixtures of $\mathrm{Fe}_{7} \mathrm{~S}_{8} / \mathrm{RP}$ and gas flow of nitrogen, air and $\mathrm{SO}_{2}$ gases are included in the table. This set of experiments included the chemical analysis and volatilization of As and $\mathrm{Sb}$. The results 
Table 5. Composition and arsenic volatilization for different samples and mixtures at $700^{\circ} \mathrm{C}$ and roasting time of 15 minutes.

\begin{tabular}{|c|c|c|c|c|c|c|c|c|c|}
\hline \multirow{2}{*}{ Experiment } & \multicolumn{2}{|c|}{$\begin{array}{l}\text { Experimental } \\
\text { Condition }\end{array}$} & \multicolumn{5}{|c|}{$\begin{array}{c}\text { Chemical } \\
\text { composition (wt\%) }\end{array}$} & \multicolumn{2}{|c|}{ Volatilization } \\
\hline & Mixture & Atmosphere & $\mathrm{Cu}$ & $\mathrm{Fe}$ & $S$ & As & $\mathrm{Sb}$ & As & $\mathrm{Sb}$ \\
\hline 18 & RP Dust & Nitrogen & 18.2 & 14.0 & 2.2 & 3.9 & 0.8 & 0.0 & 28.6 \\
\hline 19 & RP Dust & Air & 16.2 & 14.1 & 2.5 & 4.2 & 0.7 & 0.0 & 33.3 \\
\hline 20 & RP Dust & $\mathrm{SO}_{2}$ & - & - & - & 4.0 & 0.6 & 0.0 & 44.8 \\
\hline $13^{*}$ & $\begin{array}{c}\text { Copper } \\
\text { concentrate/RP } \\
\text { Dust }\end{array}$ & Air & 40.8 & 11.8 & 17.2 & 0.2 & 0.4 & 96.4 & 27.6 \\
\hline 21 & Sulfur/RP Dust & Nitrogen & 18.5 & 12.4 & 5.4 & 1.4 & 0.3 & 64.0 & 69.0 \\
\hline $17^{\star}$ & $\begin{array}{l}\text { Sulphur/RP } \\
\text { Dust }\end{array}$ & Air & 18.9 & 13.2 & 6.1 & 1.4 & 0.3 & 65.8 & 72.5 \\
\hline 22 & $\mathrm{Fe}_{7} \mathrm{~S}_{8} / \mathrm{RP}$ Dust & Air & - & - & 1.9 & 1.8 & 0.3 & 0.0 & 15.0 \\
\hline
\end{tabular}

*Experiments included in Table 4.

in Table 5 indicated negligible arsenic volatilization for the RP dust in atmospheres of nitrogen, air, and $\mathrm{SO}_{2}$. The antimony reached volatilizations of 29,33 , $45 \mathrm{wt} \%$ in the mentioned atmospheres, respectively. The pyrrhotite/RP dust mixture under the air atmosphere obtained negligible volatilization of arsenic and antimony. For copper concentrate/RP dust mixture achieved volatilization of arsenic of $96 \%$ by weight with low volatilization of antimony, close to $28 \mathrm{wt}$. The sulfur/RP dust mixture showed significant volatilization of arsenic and antimony in both atmospheres, air, and nitrogen.

\section{Discussion}

The experimental results of Table 4 for the mixture of the copper concentrate/RP dust were represented in Figure 5, indicating a strong dependence on the volatilization of arsenic with temperature and roasting time. Arsenic volatilization above $90 \%$ was obtained at temperatures of $700^{\circ} \mathrm{C}$ and a roasting time of 15 minutes.

Figure 6 represents the experimental results for a reaction time of 15 minutes for the mixture of the copper concentrate/RP dust (corresponding to experiments numbers 4, 8 and 13 of Table 4). The results indicated a strong dependence of volatilization of arsenic with temperature. The figure also include the experimental results for a reaction time of 15 minutes for the mixture of the copper sulfur/RP dust (corresponding to experiments numbers 14 -17), arsenic peaked at approximately $65 \mathrm{wt} \%$ at $650^{\circ} \mathrm{C}$, higher temperature values did not show any increment in the arsenic volatilization for this mixture. The figure also indicates a concentration of arsenic below $0.5 \mathrm{wt} \%$ for concentrate/RP dust at $700^{\circ} \mathrm{C}$. Concentration of around $1.5 \mathrm{wt} \%$ at $700^{\circ} \mathrm{C}$ for sulfur/RP dust the is quite 


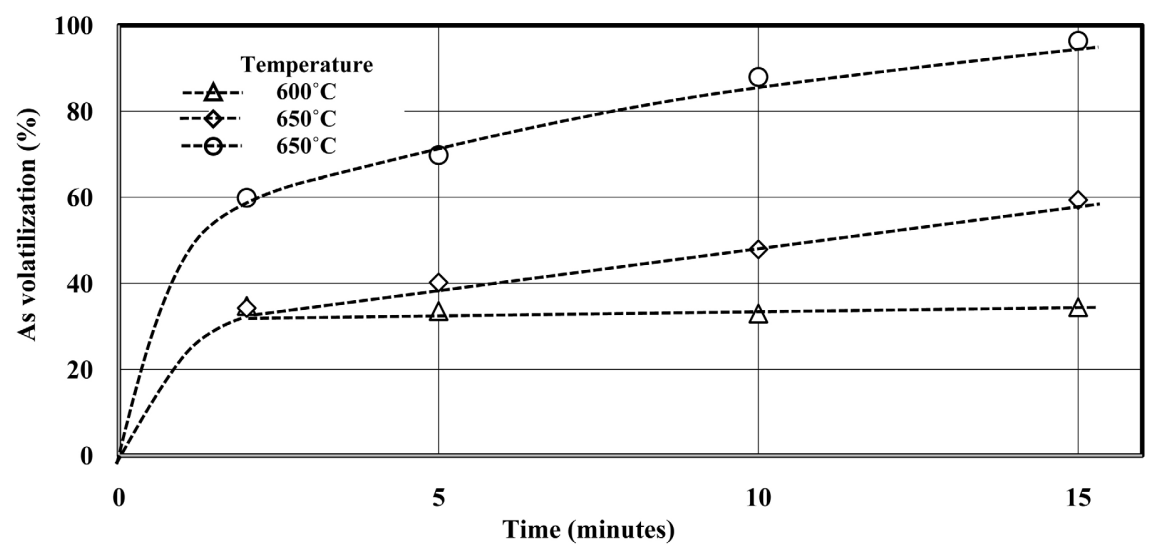

Figure 5. Relationship between the volatilization of arsenic and roasting time for a weight ratio of a mixture concentrate/RP dust of $75 / 25$ at temperatures of $600^{\circ} \mathrm{C}, 650^{\circ} \mathrm{C}$ and $700^{\circ} \mathrm{C}$.

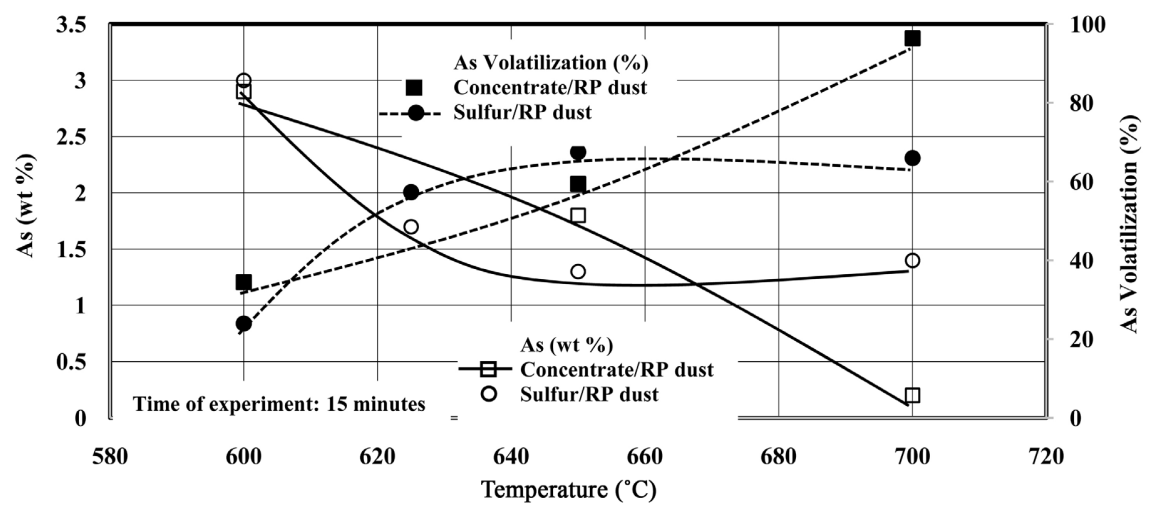

Figure 6. Volatilization of arsenic from mixtures of copper concentrate/RP dust and Sulfur/RP dust vs. temperature.

high for recycling of the roasted in a smelting furnace. Further studies are recommended to improve the arsenic volatilization of the sulfur/RP dust mixtures; a line of research is tests higher ratios of sulfur/RP dust.

The reaction mechanism of sulfidation-decomposition-oxidation proposed by SEM/EDS analysis in roasted mixtures with RP dust could not be confirmed. The results obtained indicate the absence of clear enargite/tennantite crystals. However, as indicated in Table 5, the experiment with nitrogen and air atmospheres for the sulfur/RP dust mixture showed remarkably similar results (about $65 \%)$ of arsenic volatilization for both tests. These results can be compared with those reported in the same table for RP dust roasted in a nitrogen (or air) atmosphere without the presence of sulfur, where a zero volatilization of arsenic was obtained. Therefore, it is possible to infer a process of sulfidation-volatilization of arsenic. However, verification of the reaction mechanism may be subject to further study. In addition, some questions require answers: why the mixtures of copper concentrate/RP dust reached highest arsenic volatilization, opposite to the pyrrhotite/RP dust where zero volatilization of arsenic was obtaines? What is the reason to explain that the volatilization of arsenic for the mixture concen- 
trate/Flash Smelting dust is only $10 \%$ as indicated in a previous study (13), compared with $65 \%$ for the concentrate/RP dust?

\section{Conclusions}

The characterization of RP dust indicated a morphological and crystalline composition different from Flash Smelting dust. The RP dust is composed of fine agglomerated particles $(88 \mathrm{wt} \%<10 \mu \mathrm{m})$ while the Flash Smelting dust is composed of particles with sizes between 10 and 100. The RP dust corresponds to amorphous materials and polymetallic sulfoxide, the Flash Smelting dust contains particles with a glassy matrix and crystals of iron oxides (hematite/magnetite).

Comparing the experimental results for the processing of RP dust with Flash Smelting dust, concentrate/Flash Smelting dust reached volatilization of arsenic of more than $90 \%$ at a low roasting temperature of $600^{\circ} \mathrm{C}$, in contrast, a mixture of copper concentrate/RP dust required a roasting temperature of $700^{\circ} \mathrm{C}$ to achieve similar arsenic volatilization. Despite the morphological and mineralogical differences between the RP dust and Flash Smelting dust, for a roasting temperature of $700^{\circ} \mathrm{C}$ it is possible to obtain roasting products of $>0.3 \mathrm{wt} \%$ of arsenic. Thus, RP dust and Flash Smelting dust roasted with copper concentrate are appropriate materials to be recirculated into a smelting process. The combined process of roasting of concentrate/dust and recycling in smelting has the potential to significantly reduce the tons of toxic solid waste and increase the recovery of valuable metals.

An option is recycling RP dust and Flash Smelting dust into a high arsenic concentrate fluidized bed roasting furnace. However, due to the size of the dust, operational inconveniences in the gas cleaning system and sulfuric acid production equipment can be caused. Thus, this work recommends the construction of an independent roasting furnace for the treatment of metallurgical RP dust and Flash Smelting dust.

Given the promissory results obtained with two kinds of metallurgical dust in the elimination of arsenic, it is reasonable to extend the investigation results for a similar treatment for the dust generated in the process of roasting high arsenic gold, nickel and lead-zinc concentrates.

An additional line of research corresponds to explore the recovery of silver in the gas phase in view of the differences of temperature of precipitation of compounds of silver comparing with compounds of arsenic and antimony.

The paramount importance to complement the present work is to research the fixation of the residual arsenic (antimony and bismuth) in a glassy slags matrix.

\section{Authors' Contributions}

Author Contributions: conceptualization, Héctor Henao, R. Diaz and J. Ortiz; methodology, Héctor Henao, formal analysis, Héctor Henao, R. Diaz; investigation, Héctor Henao, Ignacio Paredes, resources, R. Diaz and J. Ortiz, writing and 
editing, Héctor Henao, supervision, Héctor Henao, R. Diaz ${ }^{2}$ and J. Ortiz, funding acquisition, R. Diaz and J. Ortiz.Funding: Author Contributions: conceptualization, Héctor Henao, R. Diaz and J. Ortiz; methodology, Héctor Henao, formal analysis, Héctor Henao, R. Diaz; investigation, Héctor Henao, Ignacio Paredes, resources, R. Diaz and J. Ortiz, writing and editing, Héctor Henao, supervision, Héctor Henao, R. Diaz ${ }^{2}$ and J. Ortiz, funding acquisition, R. Diaz and J. Ortiz.

\section{Conflicts of Interest}

The authors declare no conflict of interest.

\section{References}

[1] Twidwell, L. (2019) Treatment of Arsenic-Bearing Minerals and Fixation of Recovered Arsenic Products: A Review. Society for Mining, Metallurgy \& Exploration, Englewood.

[2] Outotec Roasting Solutions (2021).

https://www.outotec.com/globalassets/products/roasting/ote outotec roasting_solu tions eng web.pdf

[3] Charitos, A., Guntner, J., Buchmann, M., Hammerschmidt, R.G., Kunch, M., Grobel, M. and Mattich, C. (2018) Method for Partial Roasting of Copper and/or Gold Bearing Concentrates. Chinese Patent No. CN107810282(A).

[4] Nazari, A.M., Radzinski, R. and Ghahreman, A. (2017) Review of Arsenic Metallurgy: Treatment of Arsenical Minerals and the Immobilization of Arsenic. Hydrometallurgy, 174, 258-281. https://doi.org/10.1016/j.hydromet.2016.10.011

[5] Robins, R.G. and Jayaweera, L.D. (1992) Arsenic in Gold Processing. Mineral Processing and Extractive Metallurgy Review, 9, 255-271. https://doi.org/10.1080/08827509208952710

[6] Caballero, D.C., Etcheverry, C.J. and Javier, O.B. (2016) Evolución Diseño y Operación Tostador de Lecho Fluidizado-DMH-CODELCO. XIV Congreso Internacional-Expomin, Santiago de Chile, 25-29 April 2016.

[7] Rebodello, C. and Parra, N. (2019) Trends and Treatment of Arsenic in Copper Mining; Copper 2019. EcoMetales Limited, Región Metropolitana.

[8] Parker, K.R. (1997) Applied Electrostatic Precipitation. First Edition, Springer, Dordrecht, 375-376. https://doi.org/10.1007/978-94-009-1553-4 1

[9] Alguacil, F.J., Magne, L., Navarro, P. and Simpson, J. (1996) Tratamiento hidrometalúrgico de los polvos de fundición de cobre. Desarsenificaciòn de las disoluciones de lixiviación. Revista de Metalurgia (Madrid), 32, 400-407. https://doi.org/10.3989/revmetalm.1996.v32.i6.888

[10] Rios, G., Ruiz, I., Cruells, M. and Roca, A. (2019) Leaching of Copper Flush Furnace Dust with Week Acid Bleed and Arsenic Precipitations as Scorodite and Arsenical Jarosite. Proceedings of the COPPER CU2019, Vancouver, 18-21 August 2019, Proceeding 591168.

[11] Adham, K., Lee, C., Francey, S. and Hussein, A. (2019) A Comparison of Roasting Technologies for Arsenic Removal from Copper Concentrates. Proceedings of the COPPER CU2019, Vancouver, 18-21 August 2019, Proceeding 538079.

[12] Walker, S.R., Jamieson, H.E., Lanzirotti, A., Hall, G.E.M. and Peterson, R.C. (2015) The Effect of Ore Roasting on Arsenic Oxidation State and Solid Phase Speciation 
in Gold Mine Tailing. Geochemistry. Exploration, Environment, Analysis, 15, $273-$ 291. https://doi.org/10.1144/geochem2013-238

[13] Henao, H., Paredes, I., Diaz, R. and Ortiz, J. (2021) Pyrometallurgical Removal of Arsenic from Electrostatic Precipitators Dusts of Copper Smelting. Journal of Minerals and Materials Characterization and Engineering, 9, 545-565.

https://doi.org/10.4236/jmmce.2021.96036

[14] Parra, R., Sepúlveda, X., Wilkomirsky, I., Parada, F. and Balladares, E. (2012) Proceso para la Remoción de Arsénico, Antimonio y Bismuto Desde Polvos de Fundición de Cobre, que Comprende Mezclado de los Polvos de Fundición con un Agente Sulfidizante, Aglomeración de la Mezcla, Sulfidización de los Compuestos Arsenicales, Volatilización y Condensación de los Sulfuros de Arsénico. Chilean Patent No. CL2012-001376.

[15] Specht, A., Kadereit, H., Schmidt, J. and Hoppe, M. (2013) Method and Device for Processing Flue Dust. U.S. Patent No. 2013/0047788A1.

[16] Yang, T., Chen, L., Liu, W., Hao, Z., Zhang, D., Xiao, Q. and Rao, S. (2015) Method for Separating and Arsenic from Arsenic-Containing Soot. Chinese Patent No. CN104294053B.

[17] Xu, B., Shi, T., Yang, B, Jiang, W., Yang, J., Liu, D., Deng, Y., Xiong, H., Li, Y. and $\mathrm{Qu}, \mathrm{T}$. (2019) Method for Removing Arsenic from Arsenic-Containing Soot. Chinese Patent No. CN109136576A. 